Article

\title{
Characterization and Hemostatic Potential of Two Kaolins from Southern China
}

\author{
Changjiao Gan ${ }^{1}{ }^{1}$, Hongjie Hu ${ }^{2}$, Zhiyun Meng ${ }^{1}$, Xiaoxia Zhu ${ }^{1}$, Ruolan Gu ${ }^{1}$, Zhuona Wu ${ }^{1}$, \\ Hongliang Wang ${ }^{2}$, Donggen Wang ${ }^{1, *}$, Hui Gan ${ }^{1, *}$, Jinglin Wang ${ }^{1, *}$ and Guifang Dou ${ }^{1}$ \\ 1 Academy of Military Medical Sciences, Beijing 100850, China \\ 2 Zhengzhou Institute of Multipurpose Utilization of Mineral Resources, Zhengzhou 450006, China \\ * Correspondence: David_king@139.com (D.W.); ganh2003@163.com (H.G.); wjlwj10801@sina.com (J.W.); \\ Tel.: +86-10-6693-1993 (H.G.)
}

Received: 4 August 2019; Accepted: 28 August 2019; Published: 30 August 2019

\begin{abstract}
The physicochemical properties and potential hemostatic application of Wenchang kaolin and Maoming kaolin were inspected and evaluated. Chemical composition analysis, Fourier transform infrared (FTIR) spectroscopy, surface area determination, X-ray diffraction, particle size, scanning electron microscopy (SEM) observations, and zeta potential analysis were performed to quantify the physical and chemical properties of the two kaolins. The results showed that both kaolins have typical FTIR bands of kaolinite with a weight fraction for kaolinite over $90 \mathrm{wt} \%$. Larger conglobate aggregates of Maoming kaolin demonstrated wider particle size distributions with two peaks at 3.17 and $35.57 \mu \mathrm{m}$, while the book-like Wenchang kaolin had narrow particle size distribution, with a frequent size of $5.64 \mu \mathrm{m}$. Furthermore, thrombelastography, the whole blood clotting tests (WBCT), plasma recalcification time (PRT) measurement, and MTT assay were performed to measure the clotting activities and biocompatibility of the two kaolins. The results showed that both kaolins could promote blood coagulation with good cytocompatibility, while Wenchang kaolin had a better procoagulant activity than Maoming kaolin. These findings demonstrated Wenchang kaolin to be a more suitable local source material for application as a hemostatic agent.
\end{abstract}

Keywords: Wenchang kaolin; hemostatic agent; Maoming kaolin; clay

\section{Introduction}

Kaolin is a versatile clay that has been widely used for different products such as ceramics, coating, water treatment, pesticides, and substrate for catalysis [1,2]. In recent years, the application of kaolin has been expanded to the field of medicine as a powerful exogenous coagulation blood material [3]. The possibility of these applications depends on the geological conditions of kaolinites, as well as their mineralogy, chemical, and physical properties such as particle distribution, color, component, and potential characteristics [1,4].

Wounds caused during surgical operations, accidents or wars may produce uncontrolled massive bleeding leading to hemorrhagic shock and death. Ideal hemostatic agents should control massive hemorrhage rapidly, while being biocompatible, stable, easy to manufacture, and low cost. In recent years, the use of several inorganic materials has been reported for accelerating blood coagulation, including zeolite, bentonite, kaolin, porous silica, and smectite [5-10]. Zeolite adsorbs plasma and concentrates blood cells but hydration of zeolite is an exothermic reaction that can cause severe burns to tissue around the wound $[11,12]$. Smectite granules (e.g., WoundStat) show high hemostatic efficacy but the granules were shown to enter the systemic circulation and cause distal thrombosis in vital organs; the product is no longer recommended by FDA for tactical combat casualty care (TCCC) $[13,14]$. Kaolin powder dispersed in nonwoven medical gauze is approved by the USA-FDA and is currently the preferred 
packing to induce clotting in arterial wounds not amenable to tourniquet application to stem blood flow. In 2008, kaolin began replacing zeolite products (QuikClot ${ }^{\circledR}$, QuikClot ${ }^{\mathrm{TM}}, \mathrm{ACS}^{\mathrm{TM}}, \mathrm{ACS}^{\mathrm{TM}}+$ ) in combat medical dressings and is marketed widely as QuikClot ${ }^{\circledR}$ Combat Gauze (QCG, Z-Medica Corporation, CT). QCG has been used in successfully stopping the bleeding from serious wounds of liver, mesentery, and femoral vessels within a minute in large animal testing [10,15-18], achieving hemostasis with a complete efficiency of $84.8 \%$ in patients [19]. It is reported that kaolin promotes clotting by activating Factor XII, in which it initiates the intrinsic clotting cascade via activating Factor XI and ends with the formation of a fibrin clot. In addition, kaolin can also promote the activation of platelet-associated Factor XI to initiate the intrinsic clotting cascade normally in Factor XII-deficient patients [20].

There are several primary kaolin deposits found in China, especially in southern China. These kaolin deposits are derived by alterations in granitic rocks, volcanic rocks, and kaolinitic sands [21]. The presence of the only large sedimentary deposit near Maoming of western Guangdong Province, China, has been reported previously, which is actually a kaolinitic sand of Late Tertiary age [22]. Most of the recent scientific studies in China have focused on understanding the use of kaolin as a raw material for catalysis and adsorption [23-26]. Few studies have been conducted to understand the properties associated with raw material selection, processing, structure, and elemental composition, which are the key determinants for hemostatic application of kaolin [11]. Two kaolins from Wenchang in Hainan Province and Maoming in Guangdong Province were collected and characterized to determine their physical and chemical properties, as well as the in vitro coagulation activity and cytocompatibility. The purpose of the work was to analyze the characteristics of two kaolinites from southern China and establish their suitability for hemostatic application. This study might reveal the structural and surface properties of kaolinites that influence the blood-clotting response.

\section{Results}

\subsection{Chemical Composition Analysis}

The results of XRF analyses are shown in Table $1 . \mathrm{SiO}_{2}$ and $\mathrm{Al}_{2} \mathrm{O}_{3}$ were found to be the major chemical compounds of both Wenchang kaolin and Maoming kaolin [27]. The results showed that there were significantly higher contents of $\mathrm{CaO}, \mathrm{K}_{2} \mathrm{O}, \mathrm{Fe}_{2} \mathrm{O}_{3}, \mathrm{Na}_{2} \mathrm{O}, \mathrm{CeO}_{2}$, and $\mathrm{Cl}$ in Wenchang kaolin than in Maoming kaolin. Here, the contents of $\mathrm{MgO}, \mathrm{CaO}$, and $\mathrm{Fe}_{2} \mathrm{O}_{3}$ may affect the hemostatic activity of the two kaolins.

Table 1. Chemical compositions of two kaolin samples (wt\%).

\begin{tabular}{ccc}
\hline Oxides & Wenchang Kaolin & Maoming Kaolin \\
\hline $\mathrm{SiO}_{2}$ & 46.950 & 46.960 \\
$\mathrm{Al}_{2} \mathrm{O}_{3}$ & 35.960 & 36.410 \\
$\mathrm{~K}_{2} \mathrm{O}$ & 1.570 & 0.664 \\
$\mathrm{Fe}_{2} \mathrm{O}_{3}$ & 1.070 & 0.784 \\
$\mathrm{TiO}_{2}$ & 0.327 & 0.407 \\
$\mathrm{Na}_{2} \mathrm{O}$ & 0.236 & 0.134 \\
$\mathrm{Cl}$ & 0.219 & 0.016 \\
$\mathrm{CaO}$ & 0.089 & 0.053 \\
$\mathrm{CeO}$ & 0.014 \\
$\mathrm{P}_{2} \mathrm{O}_{5}$ & 0.045 & 0.318 \\
$\mathrm{La}_{2} \mathrm{O}_{3}$ & 0.044 & 0.022 \\
$\mathrm{SO}_{3}$ & 0.038 & 0.176 \\
$\mathrm{MgO}$ & 0.036 & 0.034 \\
$\mathrm{Nd}_{2} \mathrm{O}_{3}$ & 0.033 & 0.004 \\
$\mathrm{ZrO}_{2}$ & 0.021 & 0.006 \\
$\mathrm{ThO}_{2}$ & 0.015 & 0.001 \\
$\mathrm{Rb}_{2} \mathrm{O}$ & 0.014 & 0.004 \\
$\mathrm{Ga}_{2} \mathrm{O}_{3}$ & 0.013 & 0.008 \\
$\mathrm{Y}_{2} \mathrm{O}_{3}$ & 0.009 & 0.002 \\
\hline
\end{tabular}


Table 1. Cont.

\begin{tabular}{ccc}
\hline Oxides & Wenchang Kaolin & Maoming Kaolin \\
\hline $\mathrm{Pr}_{6} \mathrm{O}_{11}$ & 0.004 & 0.003 \\
$\mathrm{Nb}_{2} \mathrm{O}_{5}$ & 0.004 & 0.001 \\
$\mathrm{ZnO}$ & 0.004 & 0.003 \\
$\mathrm{MnO}$ & 0.004 & 0.003 \\
$\mathrm{PbO}$ & 0.003 & 0.003 \\
$\mathrm{IrO}_{2}$ & 0.002 & 0.002 \\
$\mathrm{GeO}_{2}$ & 0.002 & 0.001 \\
$\mathrm{~V}_{2} \mathrm{O}_{5}$ & 0.001 & 0.007 \\
$\mathrm{NiO}$ & 0.001 & 0.002 \\
$\mathrm{Sc}_{2} \mathrm{O}_{3}$ & 0.001 & 0.004 \\
$\mathrm{MoO}_{3}$ & - & 0.011 \\
$\mathrm{Cr}_{2} \mathrm{O}_{3}$ & - & 0.003 \\
${ }^{\mathrm{a}} \mathrm{LO}$ & 13.28 & 13.95 \\
\hline
\end{tabular}

${ }^{\text {a }}$ LOI: loss on ignition at $980^{\circ} \mathrm{C}$.

\subsection{FTIR}

The FTIR spectra in Figure 1 shows the typical bands of kaolinite. In the region between 3700 and $3600 \mathrm{~cm}^{-1}$, the stretching frequency of $\mathrm{OH}$ bands showed four stretching bands at 3620, 3653, 3670, $3695 \mathrm{~cm}^{-1}$ [28-32]. The peaks at $3435 \mathrm{~cm}^{-1}$ in the Wenchang kaolin and $3443 \mathrm{~cm}^{-1}$ in the Maoming kaolin signify the interlayer water $\mathrm{OH}$ stretching vibration, and the peaks at $1643 \mathrm{~cm}^{-1}$ in the Wenchang kaolin and $1633 \mathrm{~cm}^{-1}$ in the Maoming kaolin pinpoint the physical adsorption of water $\mathrm{OH}$ vibration. Bands at $796 \mathrm{~cm}^{-1}$ and $753 \mathrm{~cm}^{-1}$ of Wenchang kaolin, together with $790 \mathrm{~cm}^{-1}$ and $755 \mathrm{~cm}^{-1}$ of Maoming kaolin are attributed to $(\mathrm{Al}-\mathrm{OH})$ hydroxyl groups vertical to the surface. In the spectrum between 1000 and $1120 \mathrm{~cm}^{-1}$, corresponding to Si-O stretching modes, there were observed bands at 1114, 1032, and $1008 \mathrm{~cm}^{-1}$ in the Wenchang kaolin, and at 1103,103,3 and $1005 \mathrm{~cm}^{-1}$ in the Maoming kaolin. The band at $912 \mathrm{~cm}^{-1}$ represents $\mathrm{Al}-\mathrm{Al}-\mathrm{OH}$ bonds [2], and the band at $539 \mathrm{~cm}^{-1}$ represents the Al-O-Si bending vibration [33].

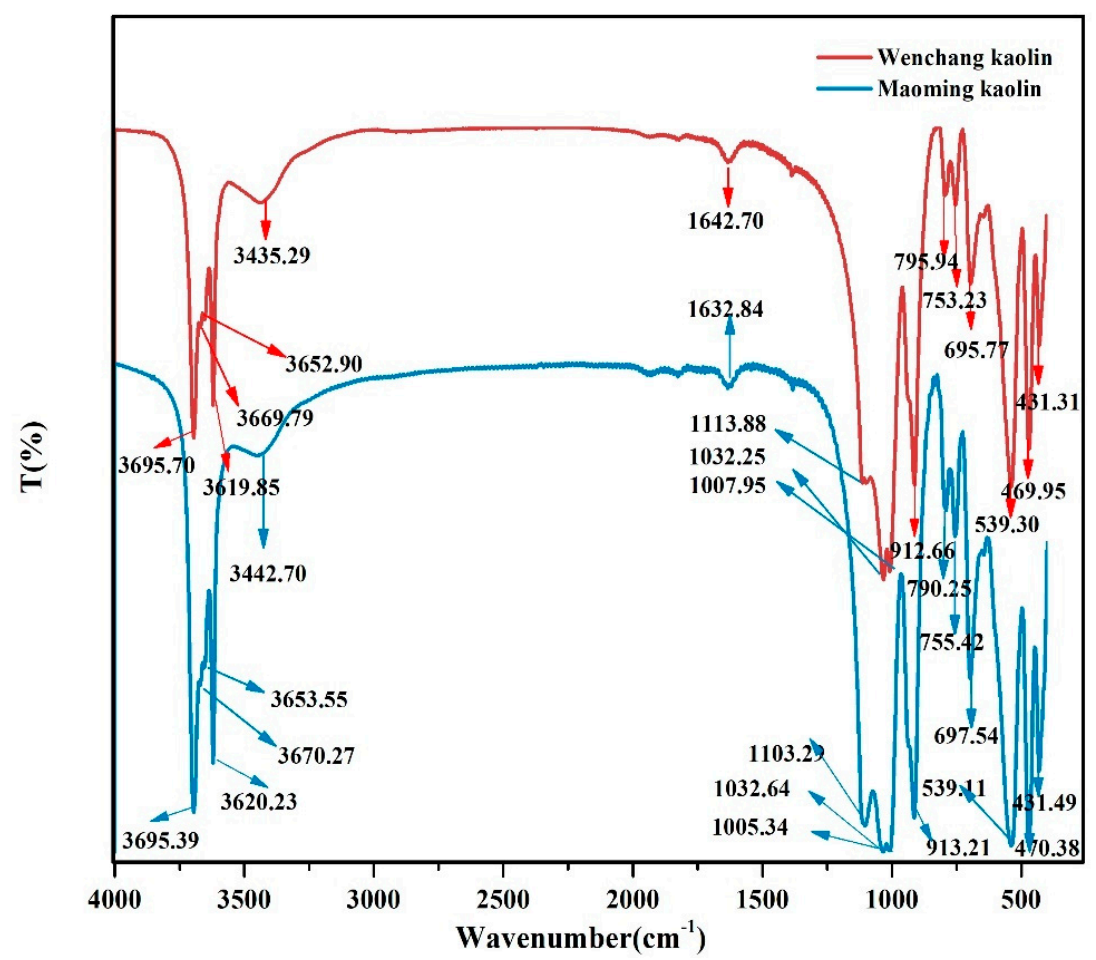

Figure 1. FTIR spectra corresponding to the Wenchang kaolin and Maoming kaolin samples. 


\subsection{XRD Analysis}

Figure 2 displays the XRD results of the two kaolin powders in the range of $2 \theta=5-65^{\circ}$. The results showed that in the two kaolin XRD patterns, both kaolinites had strong reflection, and a few reflections can be attributed to illite and quartz. By referring to the ICSD calculation data card of the minerals, quantification of the weight fraction indicated that the kaolinite weight fraction of Wenchang kaolin was $90 \mathrm{wt} \%$, illite was $8 \mathrm{wt} \%$, quartz was $2 \mathrm{wt} \%$, while the weight fraction of kaolinite in Maoming kaolin was $96 \mathrm{wt} \%$, the illite content was $3 \%$ by weight, and quartz was $1 \%$ by weight.

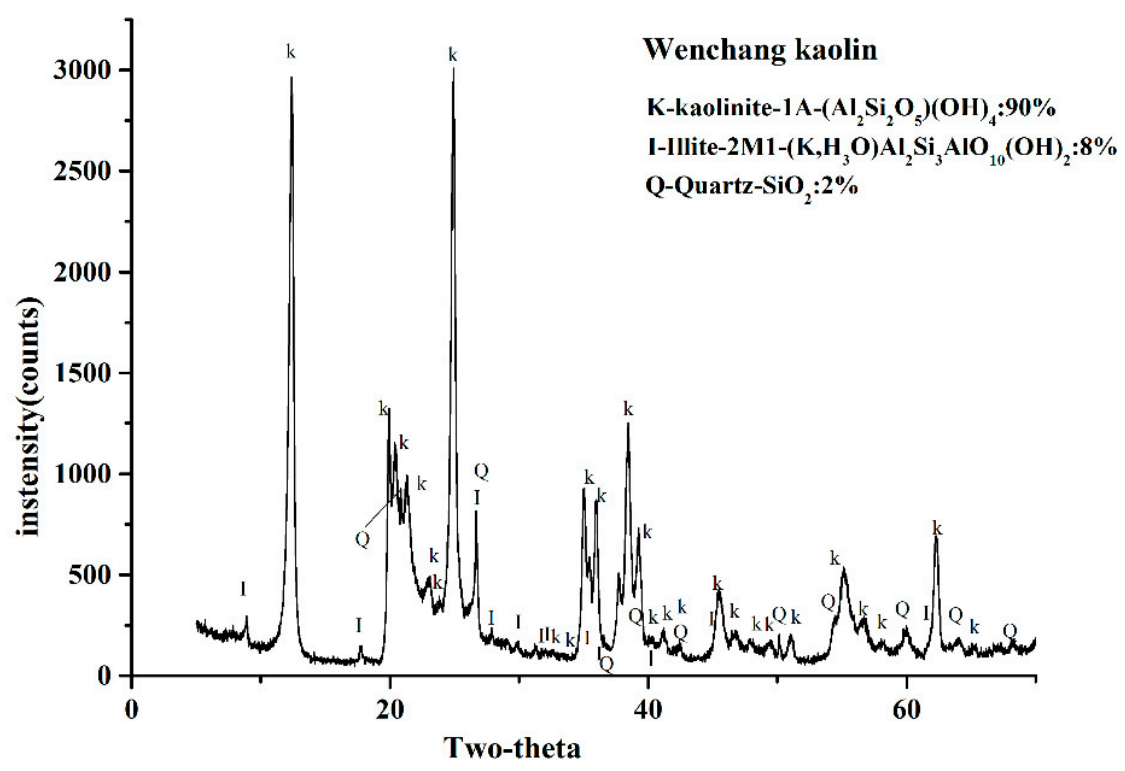

(a)

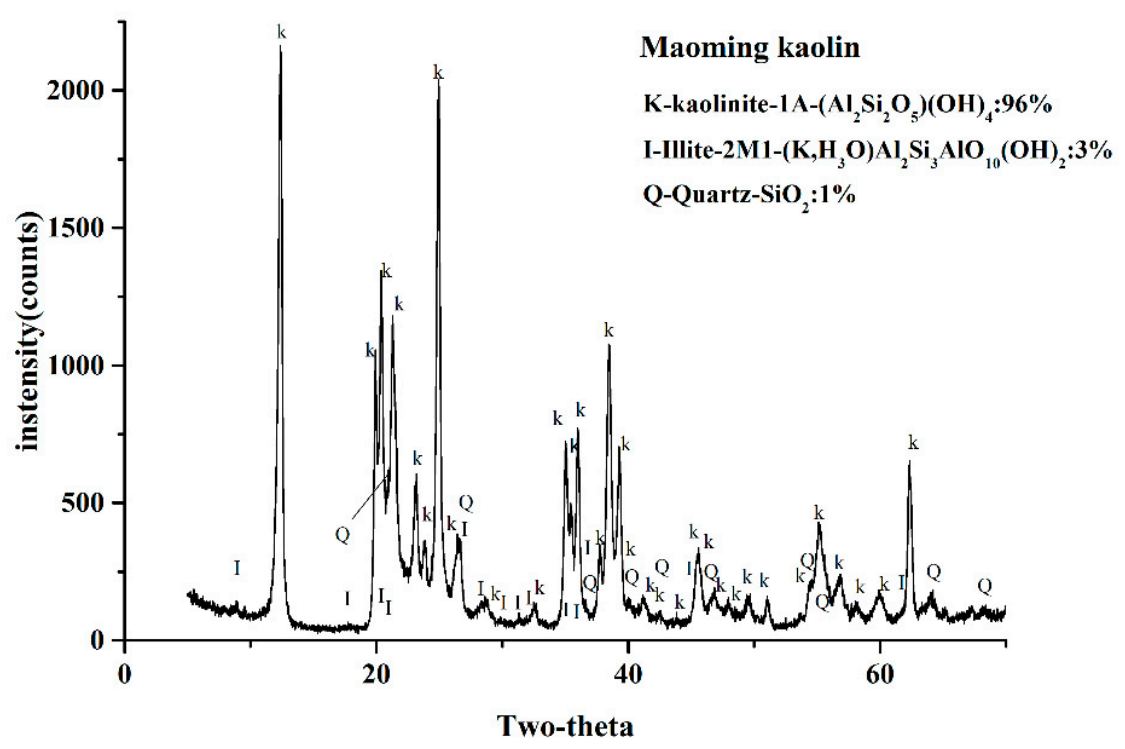

(b)

Figure 2. X-ray powder diffraction patterns of the two kaolinites.

\subsection{Particle Size Distributions}

The particle size distributions of Wenchang kaolin and Maoming kaolin are displayed in Figure 3. The results showed that the particle size of Wenchang kaolin ranged from about $0.40 \mu \mathrm{m}$ to $224.40 \mu \mathrm{m}$ and most of the particles were less than $20 \mu \mathrm{m}$. However, the particle size of Maoming kaolin ranged 
from $0.32 \mu \mathrm{m}$ to $796.21 \mu \mathrm{m}$, presenting a much wider size distribution than Wenchang kaolin. Data of the particle size index for the two kaolinites showed that the particle size cumulative volume frequency $\left(\mathrm{D}_{0.9}\right)$ of Maoming kaolin was $57.61 \pm 2.16 \mu \mathrm{m}$, indicating larger grain diameter than Wenchang kaolin with a $\mathrm{D}_{0.9}$ of $17.75 \pm 0.53 \mu \mathrm{m}$. In addition, the main frequent particle sizes of Maoming kaolin were $3.17 \mu \mathrm{m}$ and $35.57 \mu \mathrm{m}$, and the two peaks of the particle size distributions that emerged in the curve of Maoming kaolin are presented in Figure 3. Only one peak was displayed in the particle size distribution of Wenchang kaolin, with the most frequent size of $5.64 \mu \mathrm{m}$.

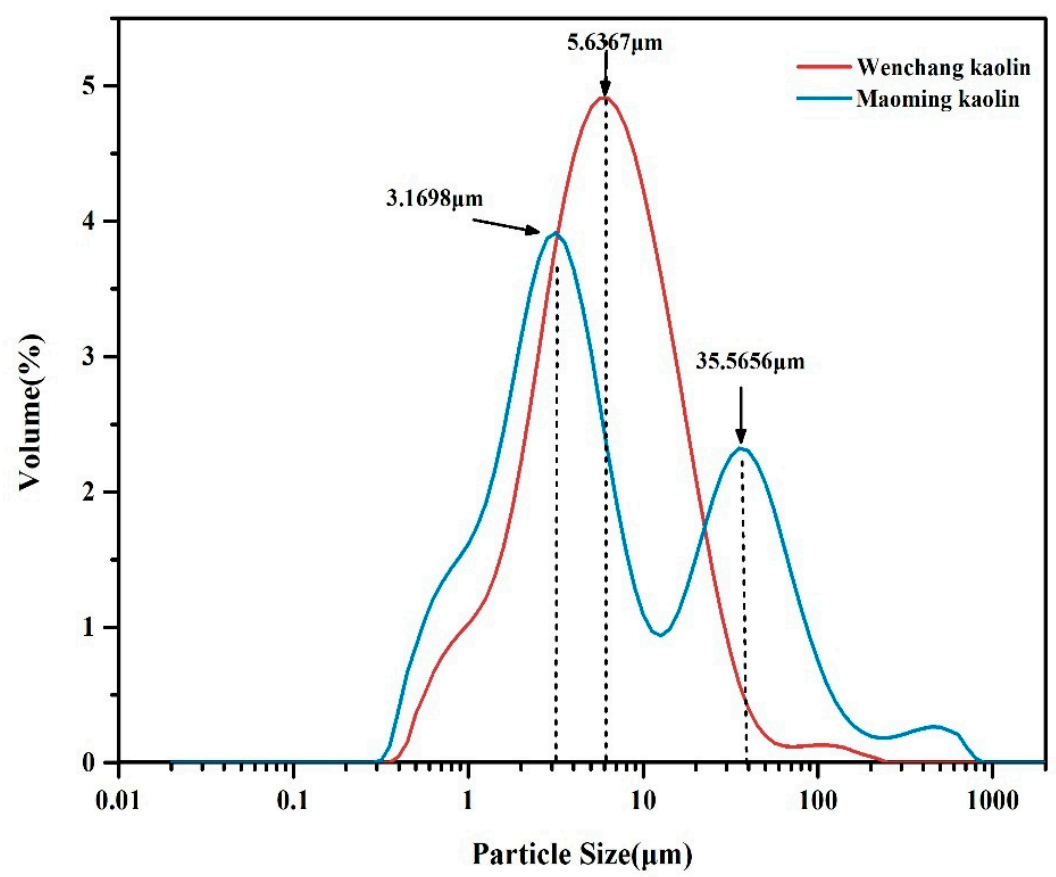

Figure 3. Particle size distribution of the two kaolins.

\subsection{Surface Area Determination}

The surface area characteristics of the two kaolinites were determined by nitrogen sorption isotherms (Table 2). The t-Plot external and BET surface area were similar between Wenchang kaolin and Maoming kaolin. The pore volume and the diameter of Maoming kaolin were a little larger than those of Wenchang kaolin. The whole blood clotting times (WBCT) of Maoming kaolin (3.88 min) was not faster than that of Wenchang kaolin $(2.88 \mathrm{~min})$, although its pore volume $\left(0.11 \mathrm{~cm}^{3} / \mathrm{g}\right)$ and diameter $(24.87 \mathrm{~nm})$ were somewhat larger than those of Wenchang kaolin $\left(0.07 \mathrm{~cm}^{3} / \mathrm{g}\right.$ and $\left.19.04 \mathrm{~nm}\right)$.

Table 2. Surface area characteristics calculated from nitrogen sorption isotherms and comparison with clotting times in whole blood of beagle dogs.

\begin{tabular}{cccccc}
\hline Materials & $\begin{array}{c}\text { BET Surface } \\
\text { Area }\left(\mathbf{m}^{2} / \mathbf{g}\right)\end{array}$ & $\begin{array}{c}\text { T-Plot External } \\
\text { Surface Area }\left(\mathbf{m}^{\mathbf{2}} / \mathbf{g}\right)\end{array}$ & $\begin{array}{c}\text { Pore Volume } \\
\left(\mathbf{c m}^{3} / \mathbf{g}\right)\end{array}$ & $\begin{array}{c}\text { Pore Diameter } \\
(\mathbf{n m})\end{array}$ & $\begin{array}{c}\text { Blood Clotting } \\
\text { Time }(\mathbf{m i n})\end{array}$ \\
\hline $\begin{array}{c}\text { Wenchang } \\
\text { kaolin }\end{array}$ & 15.18 & 18.65 & 0.07 & 19.04 & $2.88 \pm 0.25$ \\
$\begin{array}{c}\text { Maoming } \\
\text { kaolin }\end{array}$ & 17.28 & 18.00 & 0.11 & 24.87 & $3.88 \pm 0.66$ \\
\hline
\end{tabular}

\subsection{Kaolinite Micromorphology and Microtexture}

In the kaolin micrographs obtained by FESEM (Figure 4), the form and size of the particles were estimated. Both Wenchang kaolin and Maoming kaolin microscopically exhibited a typical pseudohexagonal shape; however, they displayed diverse morphologies and diameters. The layered 
structure of Wenchang kaolin demonstrated staked layers and booklet morphology (Figure 4a,b). The flat layer structure was similar to that of the typical morphology of kaolinite, which reported that the possible plate thickness is in the range of 100-150 nm [31,34] Maoming kaolin displayed a different particle size distribution, which exhibited an amount of large kaolinite particle agglomerates (Figure 4c,d). This kind of conglobate structure might be due to the strong interaction between the kaolinite charge and the surface charge of the impurities in the ore [2]. SEM images indicated that the two clays have diverse morphologies and diameters. Microscopically, the book-like Wenchang kaolin had densely packed layers, while the Maoming kaolin had larger conglobate aggregates, indicating the variations in the genesis of the two kaolins.

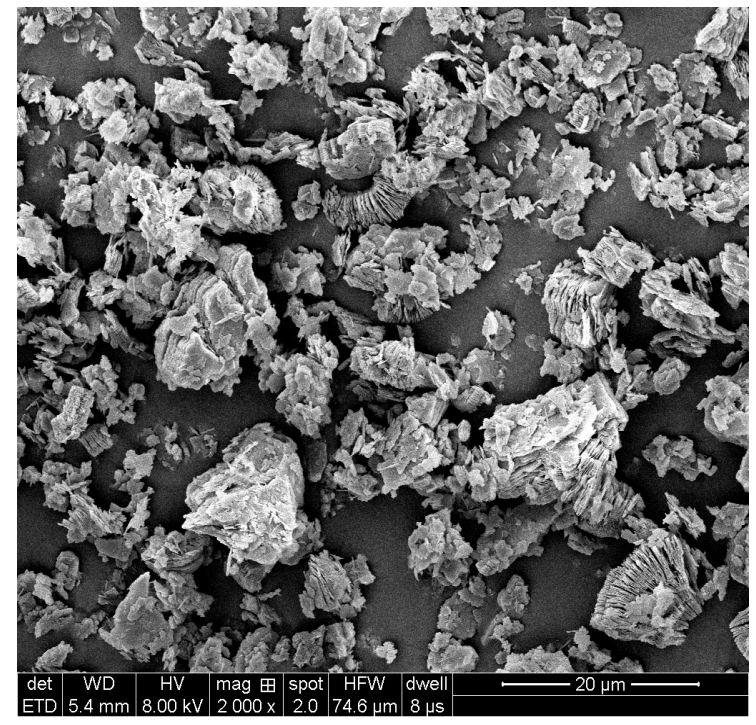

(a)

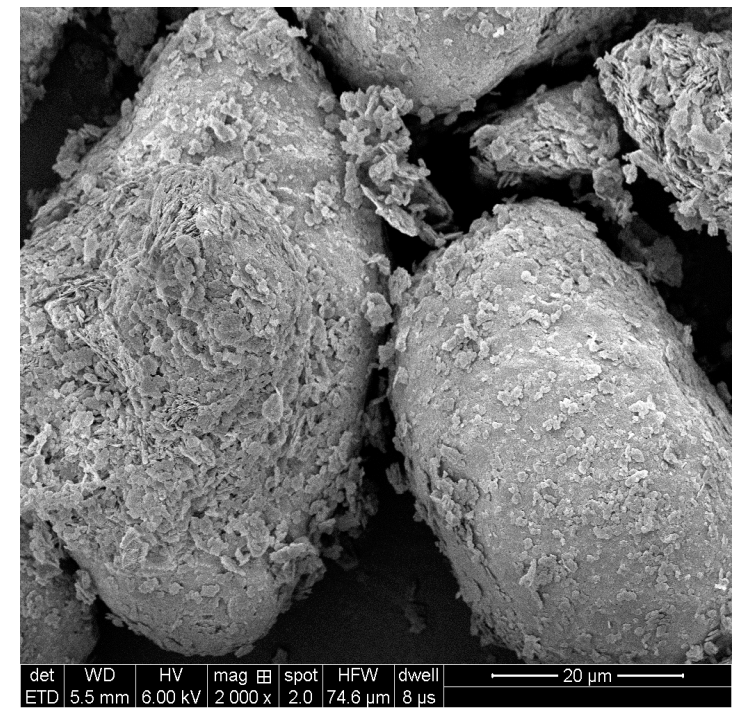

(c)

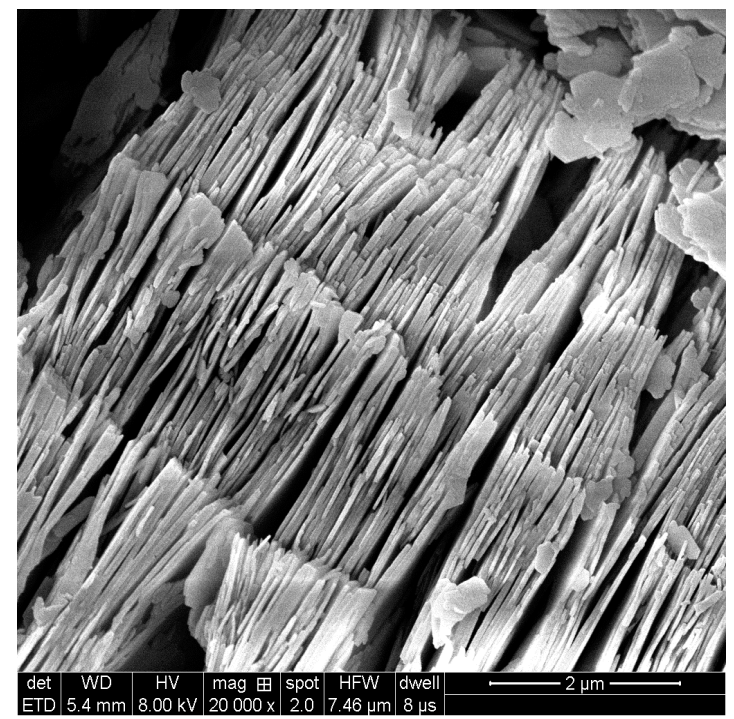

(b)

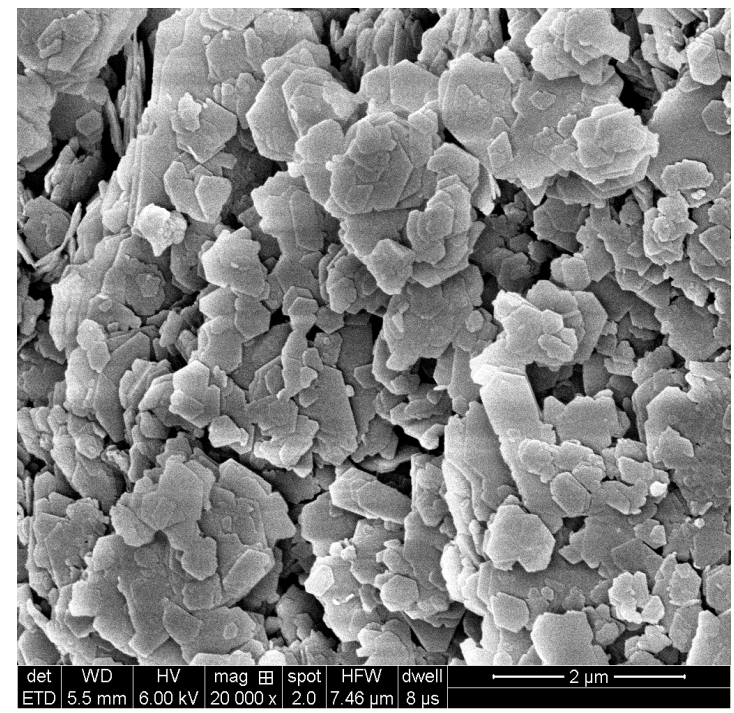

(d)

Figure 4. Field emission scanning electron microscopy (FESEM) images of Wenchang kaolin (a,b) and Maoming kaolin (c,d).

\subsection{Zeta Potential Analysis}

The zeta potentials for both kaolin samples in the $\mathrm{pH}$ range 2-12 are shown in Figure 5. At blood $\mathrm{pH}$ of 7.35-7.45, the surface charge value that was obtained between $\mathrm{pH} 6-8$ should be specifically 
focused. The results showed that both kaolinites displayed negative potentials in the pH range 4-12. Wenchang kaolin showed more negative surface charge than Maoming kaolin between pH 6 and 8 . Between $\mathrm{pH} 6$ and 8, the zeta potential of Wenchang kaolin was $-16.2 \pm 0.2 \mathrm{mV}$ to $-23.9 \pm 1.2 \mathrm{mV}$, and that of the Maoming kaolin was $-15.9 \pm 1.6 \mathrm{mV}$ to $-19.0 \pm 0.5 \mathrm{mV}$.

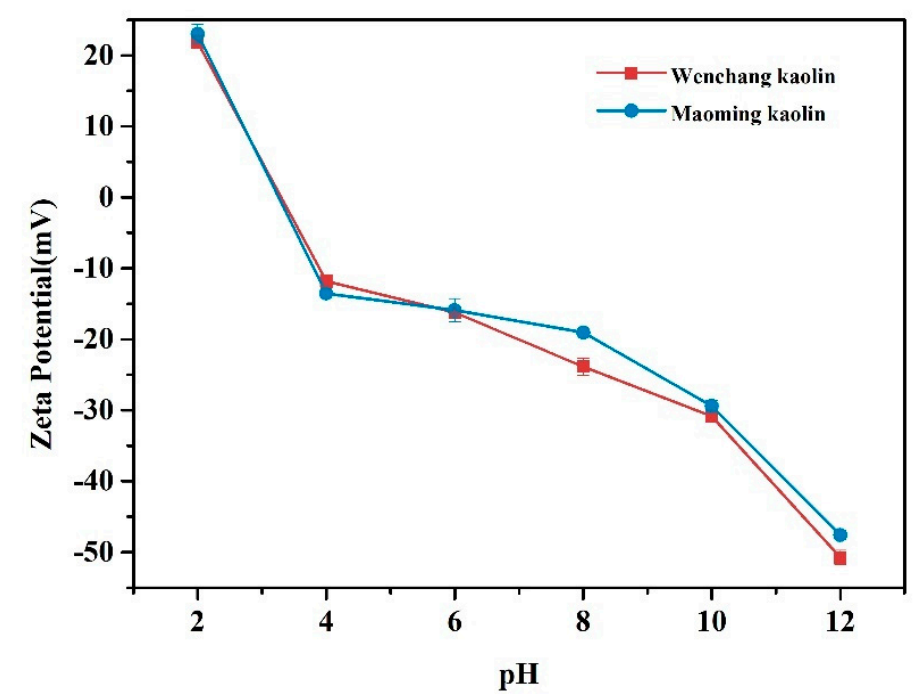

Figure 5. Zeta potential of kaolin samples with varying $\mathrm{pH}$.

\subsection{Thrombelastograph Measurements of Clotting Agents in Whole Blood}

Thrombelastography (TEG) was used to determine the clotting activities of the two kaolin samples in the whole blood of beagle dogs, which provided accurate data of initial clot initiation (R), rate of thrombus formation $(\alpha)$, and strength of the clotting (MA). As shown in Figure 6, the blood clotting activities with Wenchang kaolin suspensions and Maoming kaolin suspensions were highly increased compared to that of untreated controls. In our previous experiments, treatment of blood with the two kaolin powders initiated faster and stronger clot formation, resulting in tight TEG clotting curves. The two kaolin suspensions were used here instead of kaolin powders to reduce the dosage of kaolin. Albeit to a lesser extent, exposure to kaolin suspension still promoted faster and stronger hemagglutination than untreated controls. Meanwhile, the shorter blood clotting time (R) of Wenchang kaolin when compared with $\mathrm{R}$ of Maoming kaolin indicated that Wenchang kaolin activated coagulation more powerfully than Maoming kaolin. This showed that the two kaolin suspensions at relatively modest concentrations could also accelerate the coagulation process by activating Factor XII, leading to a significant increase in the speed of blood clot formation over untreated blood.

\subsection{In Vitro WBCT}

The blood clotting times of Wenchang kaolin and Maoming kaolin in vitro are shown in Figure 7. Similar to the TEG results, the WBCT data also showed that the blood clotting time of Maoming kaolin $(3.88 \pm 0.66 \mathrm{~min})$ was shorter than the untreated control $(6.89 \pm 0.58 \mathrm{~min}, p<0.001)$. Meanwhile, the blood clotting time of Wenchang kaolin $(2.88 \pm 0.25 \mathrm{~min})$ was much faster than Maoming kaolin $(p<0.05)$, showing statistically significant differences, and was extraordinarily shorter than the untreated control $(p<0.001)$. This indicated that Wenchang kaolin had a better procoagulant activity than Maoming kaolin. 


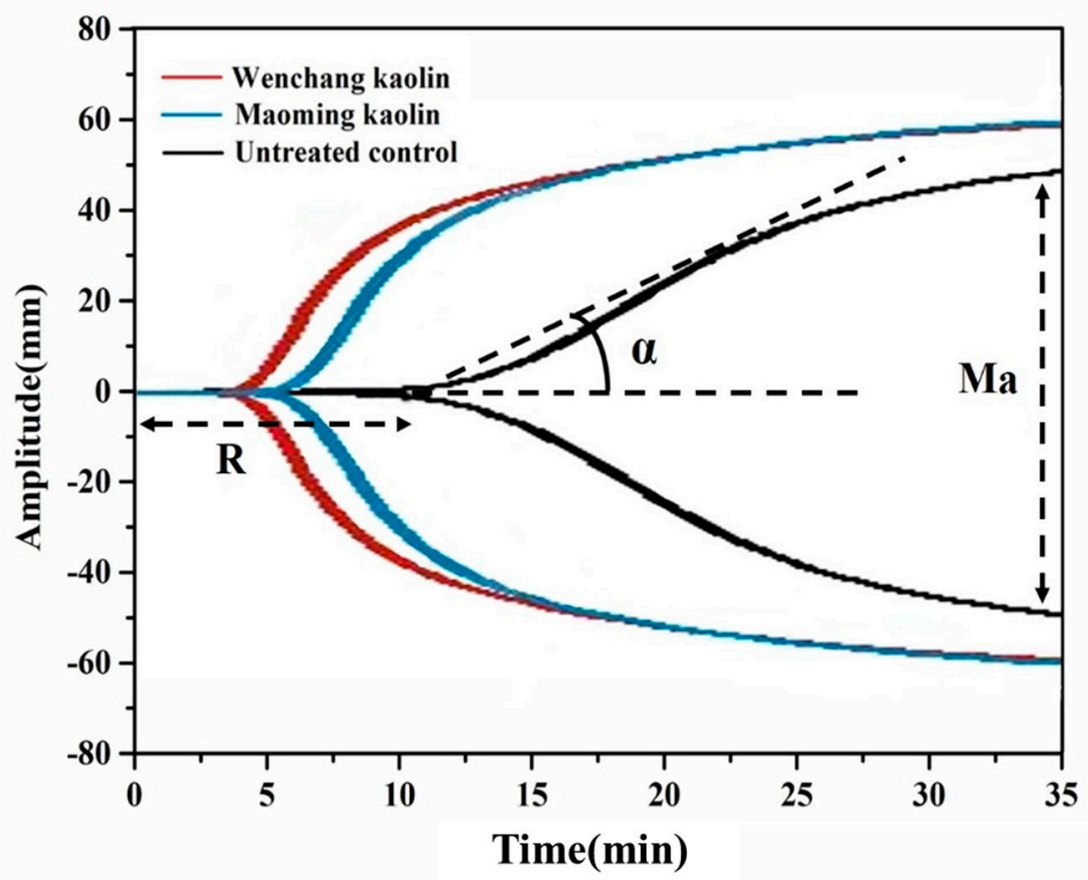

Figure 6. TEG showing the clotting characteristics of the Wenchang kaolin sample, Maoming kaolin sample, and untreated control in whole blood of beagle dogs.

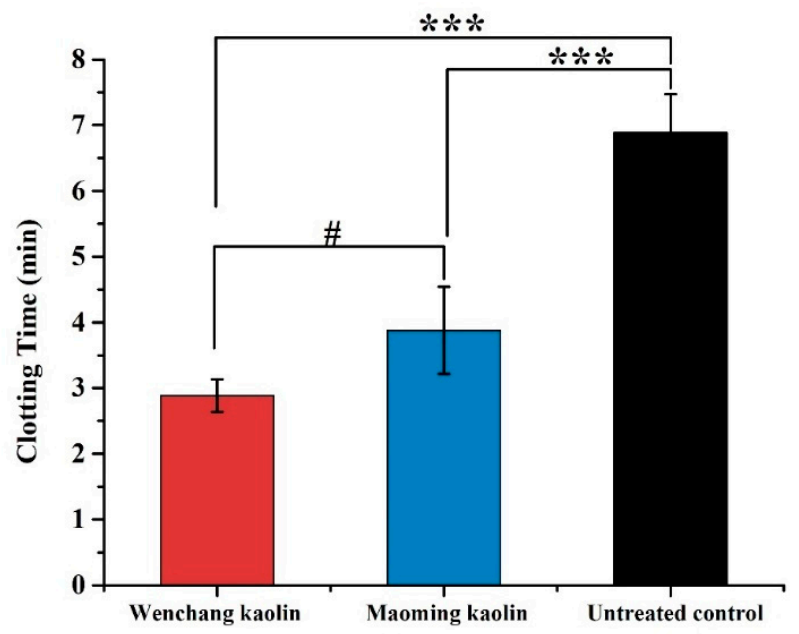

Figure 7. WBCT of two kaolins and untreated control $(n=5)$. ( ${ }^{* * *}$ indicates extraordinary difference with untreated control and $p<0.001$, \# indicates significant differences between the WBCT of the two kaolins and $0.01<p<0.05)$.

\subsection{Plasma Recalcification Time Measurement}

PRT is commonly employed as an assessment index, signing the time required for fibrin clot formation when the calcium is replenished in the anticoagulated plasma.

Figure 8 displays PRT values of Wenchang kaolin and Maoming kaolin. The data showed that the PRT of both Maoming kaolin (1.14 $\pm 0.08 \mathrm{~min})$ and Wenchang kaolin $(0.93 \pm 0.06 \mathrm{~min})$ were remarkably shorter than the untreated control $(4.98 \pm 0.28 \mathrm{~min}, p<0.001)$. Furthermore, the PRT of Wenchang kaolin was faster than Maoming kaolin $(p<0.001)$, showing statistically significant difference. The contact activation of intrinsic cascade in the plasma could vary with the type of the surface. 


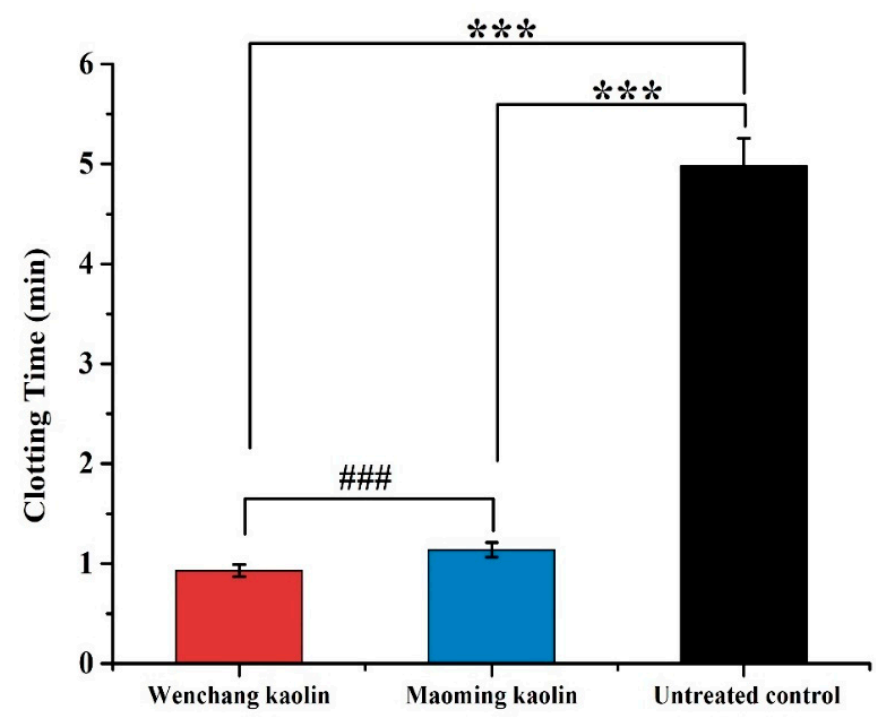

Figure 8. Plasma recalcification time (PRT)_of the two kaolin samples and the untreated control $(\mathrm{n}=6)$. (*** indicates extraordinary difference with untreated control and $p<0.001$, \#\#\# indicates extraordinary difference between the PRT of two kaolins and $p<0.001)$.

\subsection{Cell Viability Assay}

Figure 9 displays the relative growth rate (RGR\%) of L-929 cells with kaolin extractants and controls after culturing for $48 \mathrm{~h}$. The relative viability of the phenol group was only $1.99 \pm 0.14 \%$ when compared with the negative control group, which meant high cytotoxicity. Both Wenchang kaolin (with an RGR\% value of $112.28 \pm 6.84 \%, p>0.05$ ) and Maoming kaolin (with an RGR\% value of $104.89 \pm 7.67 \%, p>0.05$ ) showed noncytotoxicity and good biocompatibility against L-929 fibroblast cells after 3 days of seeding.

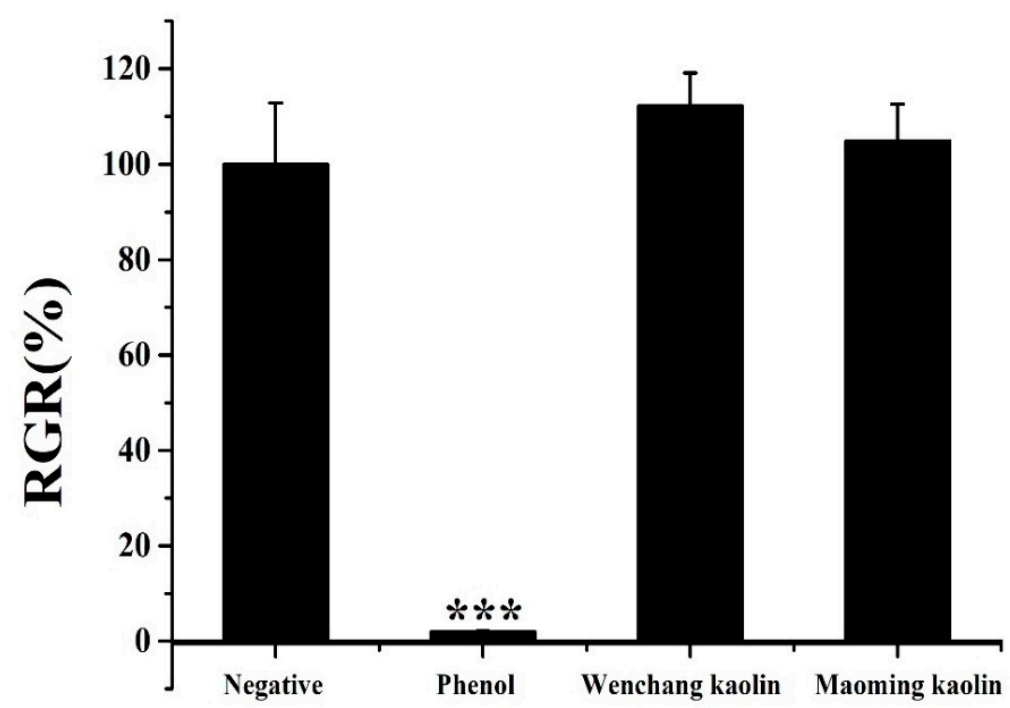

Figure 9. Biocompatibility of kaolin samples using MTT assay $(\mathrm{n}=3)$. (*** indicates extraordinary difference with untreated control and $p<0.001$ ).

\section{Discussion}

Wenchang kaolin demonstrated faster clotting activity than Maoming kaolin. It is known that the contents of $\mathrm{Ca}^{2+}$ and $\mathrm{Mg}^{2+}$ cations might affect their coagulation kinetics because of certain enzymatic reactions in the clot cascade that require $\mathrm{Ca}^{2+}$ and $\mathrm{Mg}^{2+}$ cations. In particular, $\mathrm{Ca}^{2+}$ cations are a key 
factor in promoting blood coagulation, and the $\mathrm{CaO}$ content plays a role in blood clot initiation [35,36]. Intravenous delivery of $\mathrm{Mg}^{2+}$ cations has also been developed as a candidate therapy in patients with prolonged coagulation [37]. $\mathrm{Fe}_{2} \mathrm{O}_{3}$ can facilitate $\mathrm{RBC}$ aggregation and clotting [18] and $\mathrm{Fe}_{2} \mathrm{O}_{3}$ nanoparticles have been used for tissue repair [38]. The $\mathrm{MgO}$ contents of the two samples were similar, but the $\mathrm{CaO}$ and $\mathrm{Fe}_{2} \mathrm{O}_{3}$ contents were higher in Wenchang kaolin than Maoming kaolin, which might act as an influential factor on blood clotting activation.

The FTIR spectra and XRD analysis showed that both were typical kaolinites, with a weight fraction of kaolinite of over $90 \%$ and small parts of illite and quartz, while the quantity of illite was different. The particle size, shape, and distribution are considered as important physical properties and are closely correlated with the application of clay minerals [39]. Results of particle size analysis indicated that Wenchang kaolin might be more suitable for medical application than Maoming kaolin because of its narrow and uniform particle size distribution.

For some inorganic minerals, such as zeolite, it was reported that the larger external clay BET surface area and pore volume might speed up the blood coagulation, because of its correspondingly increased water absorption, which concentrated the blood and accelerated the coagulation $[12,14,40]$. Zeolites exhibit high BET surface areas $\left(98-119 \mathrm{~m}^{2} / \mathrm{g}\right)$ and high total pore volumes $\left(0.19-0.220 \mathrm{~cm}^{3} / \mathrm{g}\right)$ [41], which in turn can rapidly absorb water at the site of bleeding in a nonchemical reaction, effectively concentrating the platelets and clotting factors to promote coagulation [12]. These results further confirmed that the main hemostatic mechanism of kaolinite does not rely on water absorption to concentrate blood, which is different from zeolite [11]. This suggests that the clay BET surface area and pore volume of kaolin may slightly influence its hemostatic performance.

Natural aluminosilicate clay has been widely used as hemostatic wound dressings. The current generation of clay-based topical hemostatic wound dressings almost exclusively contains kaolin. Kaolin, in contact with plasma, can trigger the activation of the intrinsic blood clotting cascade by binding to the positively charged amino acids present in coagulation Factor XII (Hageman factor) via the negatively charged surface of kaolin. This binding might result in subsequent conformational changes in FXII, further giving rise to the generation of active FXIIa by autoactivation. FXIIa has been confirmed to directly contribute to fibrin formation. Fibrinogen is a soluble plasma glycoprotein which can be converted to insoluble fibrin by thrombin during blood clot formation [42-45]. To make space for the growth of connective tissue cells and wound healing, the fibrin must be removed by the proteolytic system. The expression of sulfhydryls on cancer cell membranes can cause the exchange of disulfides between the polypeptide chains of fibrinogen, which results in the formation of a fibrin-like polymer (called parafibrin). Due to the presence of hydrophobic bonds in its structure, parafibrin is completely resistant to proteolytic degradation and forms a shell on the surface of tumor cells, protecting them from destruction by phagocytic cells, which is different from fibrin. Selenium is an essential trace element that occurs in nature in two inorganic forms, as selenite $\left(\mathrm{Se}^{4+}\right)$ and selenate $\left(\mathrm{Se}^{6+}\right)$, and in a number of their organic derivatives. $\mathrm{Se}^{4+}$ reacts with the $-\mathrm{SH}$ groups of proteins to prevent the formation of parafibrin on tumor cells, and thus may play a role in the treatment of cancers [46-48]. Kaolin can trigger conversion of XII to XIIa and then contribute to fibrin formation, suggesting that kaolin and its derivatives may also be used for modulation and control of the response to treat cancer and other diseases in future biomedical applications [3].

PRT is an indicator of endogenous coagulation cascade activation, and acts as an important marker for biomaterial-induced coagulation activation [49]. TEG results showed that the two kaolins significantly speed up the initial fibrin formation compared to untreated blood, and Wenchang kaolin-activated blood clotting was more powerful than that of Maoming kaolin with less blood clotting time (R). Furthermore, the WBCT and PRT were applied as indicators of material-induced coagulation activation. The data showed that WBCT and PRT of Wenchang kaolin and Maoming kaolin were remarkably shorter than the untreated control $(p<0.001)$, and Wenchang kaolin was significantly faster than Maoming kaolin $(p<0.05)$. This indicated that Wenchang kaolin had a better procoagulant activity than Maoming kaolin. In vitro cytocompatibility tests showed that both clays 
were not cytotoxic and had good cytocompatibility for L-929 fibroblasts. This suggested that the two kaolins are safe, nontoxic and suitable for biomedical applications.

\section{Materials and Methods}

\subsection{Materials}

\subsubsection{Preparation and Analysis of the Clay Minerals}

The kaolins used in this study were collected from Wenchang $\left(19^{\circ} 20^{\prime} \mathrm{N} ; 108^{\circ} 21^{\prime} \mathrm{E}\right)$ of Hainan province and Maoming $\left(22^{\circ} 42^{\prime} \mathrm{N} ; 111^{\circ} 41^{\prime} \mathrm{E}\right)$ of Guangdong province in China. The clay minerals used in this study were provided by Zhengzhou Institute of Multipurpose Utilization of Mineral Resources. Both Wenchang and Maoming kaolins were ground to acquire appropriate powders. For each clay powder, cyclone and hydraulic classification was applied, and then the feldspar and quartz sand were sieved out. Finally, the two powders were dried for $1 \mathrm{~h}$ at $300^{\circ} \mathrm{C}$ and screened with 100 mesh. Particles below 150 microns were selected for the following analysis.

\subsubsection{Experiment Materials}

RPMI 1640 medium and fetal bovine serum (FBS) were purchased from Gibco (Thermo Fisher Scientific, Waltham, MA, USA). Penicillin and streptomycin were purchased from North China Pharmaceutical Co., Ltd (Shijiazhuang, Hebei, China). NCTC clone 929 (L cell, L-929, derivative of Strain L) was obtained from the Cell bank of Chinese Academy of Sciences (Shanghai, China). Dimethyl sulfoxide (DMSO) and phenol were of analytical grade. Thiazolyl blue tetrazolium bromide (MTT) was purchased from AMRESCO (Houston, Texas, USA). Deionized water was prepared in our own laboratory.

\subsection{Chemical Composition Analysis}

The chemical compositions of the samples were measured by X-ray fluorescence (XRF) spectrometer (ARL ADVANT XP+, Thermo Fisher Scientific, Waltham, MA, USA) operating at $50 \mathrm{kV}$ and $50 \mathrm{~mA}$ with a Lawrencium target [1].

\subsection{Fourier Transform Infrared (FTIR) Spectroscopy}

Nicolet 6700 Fourier transform infrared spectrometer (Thermo Fisher Scientific, Waltham, MA, USA). was used to measure the infrared spectra of the clays The spectra were then recorded in a wavenumber range from 400 to $4000 \mathrm{~cm}^{-1}$ with 32 scans per spectrum and a resolution of $4 \mathrm{~cm}^{-1}$ [2].

\subsection{X-ray diffraction (XRD) Measurements}

X-ray powder diffraction of the two kaolin samples was performed on an Xpert Pro MPD diffractometer (XRD, Malvern Panalytica, Eindhoven, Netherlands), which was operated at $40 \mathrm{kV}$ and $40 \mathrm{~mA}$ with a $\mathrm{Cu} \mathrm{K} \alpha(\lambda=1.5406 \AA)$ radiation. The samples were air desiccated and placed on the spinner of XRD, followed by scanning for $2 \theta$ ranging from $5^{\circ}$ to $90^{\circ}$ with a scan rate of $4 \% \mathrm{~min}$ and a step size of 0.02 [2,50]. Mineral compositions of the two clays were identified with JADE6.5 software. Inorganic Crystal Structure Database (ICSD) and Rietveld analysis were adopted to obtain the relative fractions in different phases for the two samples.

\subsection{Particle Size Distribution}

Particle size distribution was analyzed on Malvern Mastersizer 2000 (Malvern, UK) [1,2]. All samples were sonicated for $30 \mathrm{~min}$ before measurement. Each sample was tested thrice and expressed as mean values. The particle size characteristics included the average particle size $\left(\mathrm{D}_{0.5}\right)$ and the particle size cumulative volume frequency $\left(\mathrm{D}_{0.1}, \mathrm{D}_{0.9}\right)$. 


\subsection{Surface Area Determination}

A Micrometrics ASAP 2460 (Norcross, Georgia, USA) was used for nitrogen gas sorption analysis of clay surface areas [11,51]. Prior to the surface area measurement, clays were dried at $200{ }^{\circ} \mathrm{C}$ for $12 \mathrm{~h}$ under nitrogen. Data were calculated using MicroActive 2.01 analysis (Norcross, Georgia, USA).

\subsection{Scanning Electron Microscopy (SEM) Analysis}

A scanning electron microscope (Quanta FEG 250, Hillsboro, Oregon, USA) was employed to observe the morphology of the clays [1,4]. The kaolin powders were sputtered with a thin layer of platinum to increase their electrical conductivity on a Leica EM SCD 500 at $16 \mathrm{~mA}$ with $120 \mathrm{~s}$ before field emission scanning electron microscopy (FESEM) analysis.

\subsection{Zeta Potential Analysis}

Prior to the analysis, a series of aqueous solutions in the $\mathrm{pH}$ range $2-12$ were prepared $[2,18]$. Kaolin samples were dispersed at a concentration of $0.1 \mathrm{mg} / \mathrm{mL}$ in the aqueous solutions. The measurements were made in polystyrene cuvettes on a Malvern Zetasizer Nano S90 (Malvern, United Kingdom). Each measurement was made in triplicate at $25^{\circ} \mathrm{C}$ using monomodal analysis and 12 cycles of runs. Between each sample, the dip cell electrode was rinsed and sonicated in deionized water for $3 \mathrm{~min}$.

\subsection{Thrombelastograph Measurements of Clotting Agents in Whole Blood}

A Hemoscope Thrombelastrograph ${ }^{\mathrm{TM}}$ (TEG Hemostasis Analyzer 5000, Haemoscope, Niles, IL, USA) was chosen to assess the coagulation activity of the clays investigated [52,53]. It can provide quantitative data including the reaction time until clot formation $(\mathrm{R})$, the rate of thrombus generation $(\alpha)$ and the maximum amplitude (MA) by measuring the torsion around a wire during blood clotting period.

Firstly, $1 \mathrm{~mL}$ fresh citrate-stabilized whole blood of beagle dog was prepared in each plastic vial, followed by immediate addition of $20 \mu \mathrm{L}(0.1 \mathrm{mg} / \mathrm{mL})$ of each kaolin suspension, and then gentle inversion of the mixture. Next, $20 \mu \mathrm{L}$ of $\mathrm{CaCl}_{2}(0.2 \mathrm{M})$ was placed in a plastic sample cup and then heated to $37^{\circ} \mathrm{C}$. Finally, $340 \mu \mathrm{L}$ whole blood mixed with kaolin suspension was added to the sample cup, which was loaded into position for beginning the test. The citrate-stabilized whole blood without kaolin treatment was tested as blank control. Five beagle dogs were used in this experiment.

\subsection{In Vitro Whole Blood Clotting Tests (WBCT)}

Five milligram clay samples were placed in flat-bottom glass vials and preheated at $37^{\circ} \mathrm{C}$. Then, $1 \mathrm{~mL}$ fresh whole beagle dog blood was slowly added into each vial and gently inverted for $3 \mathrm{~s}$. The time was checked immediately after adding the whole blood. The vials were incubated at $37^{\circ} \mathrm{C}$ and tilted every $10 \mathrm{~s}$ for observation. WBCT was performed to measure the time when the blood was totally coagulated. The blood sample without any addition of clay was tested in parallel as the untreated control group [54]. Five parallel tests were performed for each sample by using five beagle dogs in this experiment. All animal experiments were done with the permission of Institute of Animal Care and Use Committee (IACUC) at the Academy of Military Medical Sciences (AMMS). The ethical approval number was IACUC of AMMS-13-2017-017. IACUC of AMMS-13- 2016-017.

\subsection{Plasma Recalcification Time (PRT) Measurement}

Fresh New Zealand rabbits' blood was collected and mixed with sodium citrate solution in tubes immediately. The anticoagulated whole blood was then subsequently centrifuged at $3000 \mathrm{rpm}$ for $15 \mathrm{~min}$, and the upper plasma was platelet-poor plasma (PPP). Each test tube with $0.1 \mathrm{~mL}$ PPP was prepared, and $0.1 \mathrm{~mL}$ of kaolin in suspension at a concentration of $1 \mathrm{mg} / \mathrm{mL}$ was joined and mixed quickly. Normal saline was used as a negative control to kaolin. Each tube was incubated at $37^{\circ} \mathrm{C}$ for $3 \mathrm{~min}$, followed by the addition of $0.1 \mathrm{~mL} \mathrm{CaCl}_{2}$ solution to start plasma recalcification measurement. 
The time was recorded as the PRT when silky fibrin appeared in the mixture, which denoted clot formation [44]. The experiment was repeated 6 times and an average value was obtained.

\subsection{Cell Viability Assay}

The MTT method was universally employed for evaluating material biocompatibility $[18,55,56]$. L-929 mouse fibroblast cells were cultured in RPMI 1640 medium with $10 \%$ FBS at $37^{\circ} \mathrm{C}$. The kaolin samples were sterilized via $\mathrm{Co}_{60}$ gamma irradiation at a dose of $25 \mathrm{kGy}$ and incubated in RPMI 1640 medium at $37^{\circ} \mathrm{C}$ for $24 \mathrm{~h}$. Then, the extractants of the samples incubated were gathered after centrifugation.

L-929 cells at a density of $5 \times 10^{3}$ cells per well were spread in a 96-well plate and incubated for $24 \mathrm{~h}$ for cell attachment. Then, the extractants of the kaolins replaced the culture medium to be incubated with the cells for $48 \mathrm{~h}$. After interaction, MTT solution was used for another $4 \mathrm{~h}$ exposure. After that, the extractant medium was drawn out and $150 \mu \mathrm{L}$ DMSO was filled to dissolve the formazan crystals. An ELISA reader (SpectraMax 190) was used to measure the absorbance of formazan solution at $490 \mathrm{~nm}$. The negative control was cells in the fresh culture medium, and the positive control was cells in the culture medium that contained $0.30 \%$ phenol. Cell viability was denoted with relative growth rate (RGR\%), which was calculated by using the Equation (1):

$$
\operatorname{RGR}(\%)=\mathrm{A}_{\text {sample }} / \mathrm{A}_{\text {negative }} \times 100 \%
$$

where $A_{\text {sample }}$ represents absorbance of samples and $A_{\text {negative }}$ represents negative control.

\subsection{Data Analysis}

Data was expressed as mean $\pm \mathrm{SD}$ (standard deviation). The differences between experimental groups were compared by Student's t-test. A $p$-value of less than 0.05 ( $95 \%$ level) was considered to be statistically significant.

\section{Conclusions}

Based on our analysis, both Wenchang and Maoming kaolin were typical kaolinites with good hemostatic activity, and Wenchang kaolin is better than Maoming kaolin. They could be applied for controlling bleeding following traumatic injury as locally sourced materials in China, and be developed as a positive activator for a TEG detection kit. This study also suggests that the $\mathrm{MgO}, \mathrm{CaO}$, and $\mathrm{Fe}_{2} \mathrm{O}_{3}$ contents, particle size and distribution, and zeta potential of the kaolin may influence its hemostatic performance. Cytotoxicity evaluation in vitro highlighted that both kaolins have good biocompatibility for tissue cells. Some kaolin-based hemostatic agents have been developed to prevent massive blood loss, contributing to making the hemostatic process easier and shorter. To further demonstrate the clinical potential of kaolin-based composites, future studies will be conducted on hemorrhage models, which will produce further scientific evidence for the use of kaolin-based composites for bleeding control.

Author Contributions: Conceptualization, H.G., J.W., D.W. and G.D.; Methodology, C.G. and H.G.; Project administration, G.D.; Resources, H.H. and H.W.; Software, C.G., R.G. and Z.W.; Supervision, Z.M. and X.Z.; Writing-original draft, C.G.; all authors contributed to review and editing of the manuscript.

Funding: The authors gratefully acknowledge financial support from Chinese National Science and Technology Key Projects for the financial assistance (2016ZX09J16103-001-001).

Conflicts of Interest: The authors declare no conflict of interest. 


\section{References}

1. Yaya, A.; Tiburu, E.K.; Vickers, M.E.; Efavi, J.K.; Onwona-Agyeman, B.; Knowles, K.M. Characterisation and identification of local kaolin clay from Ghana: A potential material for electroporcelain insulator fabrication. Appl. Clay Sci. 2017, 150, 125-130. [CrossRef]

2. Segura, J.C.F.; Cruz, V.E.R.; Ascencio, E.M.L.; García, F.L. Characterization and electrochemical treatment of a kaolin. Appl. Clay Sci. 2017, 146, 264-269. [CrossRef]

3. Awad, M.E.; Lopez-Galindo, A.; Setti, M.; El-Rahmany, M.M.; Iborra, C.V. Kaolinite in pharmaceutics and biomedicine. Int. J. Pharm. 2017, 533, 34-48. [CrossRef] [PubMed]

4. Pruett, R.J. Kaolin deposits and their uses: Northern Brazil and Georgia, USA. Appl. Clay Sci. 2016, 131, 3-13. [CrossRef]

5. Ward, K.R.; Tiba, M.H.; Holbert, W.H.; Blocher, C.R.; Draucker, G.T.; Proffitt, E.K.; Bowlin, G.L.; Ivatury, R.R.; Diegelmann, R.F. Comparison of a new hemostatic agent to current combat hemostatic agents in a Swine model of lethal extremity arterial hemorrhage. J. Trauma 2007, 63, 276-284. [CrossRef]

6. Khoshmohabat, H.; Dalfardi, B.; Dehghanian, A.R.; Rasouli, H.R.; Mortazavi, S.M.J.; Paydar, S. The effect of CoolClot hemostatic agent on skin wound healing in rats. J. Surg. Res. 2016, 732-737. [CrossRef] [PubMed]

7. Kheirabadi, B. Evaluation of topical hemostatic agents for combat wound treatment. US Army Med. Dep. J. 2011, 4-6, 25-37.

8. Carraway, J.W.; Kent, D.; Young, K.; Cole, A.; Friedman, R.; Ward, K.R. Comparison of a new mineral based hemostatic agent to a commercially available granular zeolite agent for hemostasis in a swine model of lethal extremity arterial hemorrhage. Resuscitation 2008, 78, 230-235. [CrossRef]

9. Zhang, Y.J.; Gao, B.; Liu, X.W. Topical and effective hemostatic medicines in the battlefield. Int. J. Clin. Exp. Med. 2015, 8, 10-19.

10. Englehart, M.S.; Cho, S.D.; Tieu, B.H.; Morris, M.S.; Underwood, S.J.; Karahan, A.; Schreiber, M.A. A novel highly porous silica and chitosan-based hemostatic dressing is superior to HemCon and gauze sponges. J. Trauma 2008, 65, 884-890. [CrossRef]

11. Baker, S.E.; Sawvel, A.M.; Zheng, N.; Stucky, G.D. Controlling Bioprocesses with Inorganic Surfaces: Layered Clay Hemostatic Agents. Chem. Mater. 2007, 19, 4390-4392. [CrossRef]

12. Li, Y.; Liao, X.; Zhang, X.; Ma, G.; Zuo, S.; Xiao, L.; Stucky, G.D.; Wang, Z.; Chen, X.; Shang, X. In situgenerated thrombin in the protein corona of zeolites: Relevance of the functional proteins to its biological impact. Nano Res. 2014, 7, 1457-1465. [CrossRef]

13. Li, G.; Quan, K.; Liang, Y.; Li, T.; Yuan, Q.; Tao, L.; Xie, Q.; Wang, X. Graphene-Montmorillonite Composite Sponge for Safe and Effective Hemostasis. ACS Appl. Mater. Interfaces 2016, 8, 35071-35080. [CrossRef] [PubMed]

14. Pourshahrestani, S.; Zeimaran, E.; Djordjevic, I.; Kadri, N.A.; Towler, M.R. Inorganic hemostats: The state-of-the-art and recent advances. Mater. Sci. Eng. C Mater. Biol. Appl. 2016, 58, 1255-1268. [CrossRef] [PubMed]

15. Trabattoni, D.; Gatto, P.; Bartorelli, A.L. A new kaolin-based hemostatic bandage use after coronary diagnostic and interventional procedures - International Journal of Cardiology. Int. J. Cardiol. 2012, 156, 53-54. [CrossRef] [PubMed]

16. Sena, M.J.; Geoffrey, D.; Gerlach, T.; Grayson, J.K.; Pichakron, K.O.; Dustin, Z. A pilot study of the use of kaolin-impregnated gauze (Combat Gauze) for packing high-grade hepatic injuries in a hypothermic coagulopathic swine model. J. Surg. Res. 2013, 183, 704-709. [CrossRef]

17. Trabattoni, D.; Montorsi, P.; Fabbiocchi, F.; Lualdi, A.; Gatto, P.; Bartorelli, A.L. A new kaolin-based haemostatic bandage compared with manual compression for bleeding control after percutaneous coronary procedures. Eur. Radiol. 2011, 21, 1687-1691. [CrossRef] [PubMed]

18. Long, M.; Zhang, Y.; Huang, P.; Chang, S.; Hu, Y.; Yang, Q.; Yang, H. Emerging Nanoclay Composite for Effective Hemostasis. Adv. Funct. Mater. 2018, 28, 1704452. [CrossRef]

19. Chávez, M.E. Topic usage of kaolin-impregnated gauze as a hemostatic in tonsillectomy. J. Surg. Res. 2014, 192, 678-685. [CrossRef]

20. Gegel, B.; Burgert, J.; Gasko, J.; Campbell, C.; Martens, M.; Keck, J.; Reynolds, H.; Loughren, M.; Johnson, D. The effects of QuikClot Combat Gauze and movement on hemorrhage control in a porcine model. Mil. Med. 2012, 177, 1543-1547. [CrossRef] 
21. Wilson, I.R. Kaolin and halloysite deposits of China. Clay Miner. 2004, 39, 1-15. [CrossRef]

22. Yuan, J.; Murray, H.H. Mineralogical and Physical Properties of the Maoming Kaolin from Guandong Province, South China. Clay Miner. Soc. Spec. Pub. 1990, 1, 249-259.

23. Zhu, X.; He, J.; Su, S.; Zhang, X.; Wang, F. Concept model of the formation process of humic acid-kaolin complexes deduced by trichloroethylene sorption experiments and various characterizations. Chemosphere 2016, 151, 116-123. [CrossRef] [PubMed]

24. Lin, J.; Sun, M.; Liu, X.; Chen, Z. Functional kaolin supported nanoscale zero-valent iron as a Fenton-like catalyst for the degradation of Direct Black G. Chemosphere 2017, 184, 664-672. [CrossRef] [PubMed]

25. Zhao, C.; Zheng, H.; Sun, Y.; Zhang, S.; Liang, J.; Liu, Y.; An, Y. Evaluation of a novel dextran-based flocculant on treatment of dye wastewater: Effect of kaolin particles. Sci. Total Environ. 2018, 640, 243-254. [CrossRef] [PubMed]

26. Qu, M.; Ma, X.; He, J.; Feng, J.; Liu, S.; Yao, Y.; Hou, L.; Liu, X. Facile selective and diverse fabrication of superhydrophobic, superoleophobic-superhydrophilic and superamphiphobic materials from kaolin. ACS Appl. Mater. Interfaces 2016, 9, 1011-1020. [CrossRef] [PubMed]

27. Konduri, M.K.R.; Fatehi, P. Dispersion of kaolin particles with carboxymethylated xylan. Appl. Clay Sci. 2017, 137, 183-191. [CrossRef]

28. Liu, Q.; Shuai, Z.; Cheng, H.; Ding, W.; Li, X.; Hou, X.; Frost, R.L. Thermal behavior of kaolinite-urea intercalation complex and molecular dynamics simulation for urea molecule orientation. J. Therm. Anal. Calorim. 2014, 117, 189-196. [CrossRef]

29. Bich, C.; Ambroise, J.; Péra, J. Influence of degree of dehydroxylation on the pozzolanic activity of metakaolin. Appl. Clay Sci. 2009, 44, 194-200. [CrossRef]

30. Ece, O.I.; Nakagawa, Z.E.; Schroeder, P. Alteration of volcanic rocks and genesis of kaolin deposits in the sile region, northern Istanbul, Turkey. I: Clay mineralogy. Clay Miner. 2003, 51, 675-688.

31. Irfan Khan, M.; Khan, H.U.; Azizli, K.; Sufian, S.; Man, Z.; Siyal, A.A.; Muhammad, N.; Faiz ur Rehman, M. The pyrolysis kinetics of the conversion of Malaysian kaolin to metakaolin. Appl. Clay Sci. 2017, 146, $152-161$. [CrossRef]

32. Cheng, H.; Xu, P.; Ding, W.; Frost, R.L. Thermal decomposition behavior and de-intercalation kinetics of kaolinite/quaternary ammonium salt complexes. J. Therm. Anal. Calorim. 2016, 126, 1-13. [CrossRef]

33. Souri, A.; Golestani-Fard, F.; Naghizadeh, R.; Veiseh, S. An investigation on pozzolanic activity of Iranian kaolins obtained by thermal treatment. Appl. Clay Sci. 2015, 103, 34-39. [CrossRef]

34. Lee, S.; Kim, Y.J.; Moon, H.S. Energy-Filtering Transmission Electron Microscopy (EF-TEM) Study of a Modulated Structure in Metakaolinite, Represented by a $14 \AA$ A Modulation. J. Am. Ceram. Soc. 2010, 86, 174-176. [CrossRef]

35. Mehrosadat, A.; Alireza, T.; Mohammad Ali, O.; Motahareh, M.; Peyman, R.; Mohammad, A. The effect of a new impregnated gauze containing bentonite and halloysite minerals on blood coagulation and wound healing. Blood Coagul. Fibrinolysis 2014, 25, 856-859.

36. Ostomel, T.A.; Qihui, S.; Stoimenov, P.K.; Stucky, G.D. Metal oxide surface charge mediated hemostasis. Langmuir ACS J. Surf. Colloids 2007, 23, 11233-11238. [CrossRef] [PubMed]

37. Choi, J.H.; Lee, J.; Park, C.M. Magnesium therapy improves thromboelastographic findings before liver transplantation: A preliminary study. Can. J. Anaesth. 2005, 52, 156-159. [CrossRef] [PubMed]

38. Anne, M.-P.; Aurélie, L.; Alba, M.; Liliane, L.; Didier, L.; Ludwik, L. Organ repair, hemostasis, and in vivo bonding of medical devices by aqueous solutions of nanoparticles. Angew. Chem. 2014, 53, 6369-6373.

39. Murray, H.H. Traditional and new applications for kaolin, smectite, and palygorskite: A general overview. Appl. Clay Sci. 2000, 17, 207-221. [CrossRef]

40. Li, J.; Cao, W.; Lv, X.-X.; Jiang, L.; Li, Y.-J.; Li, W.-Z.; Chen, S.-Z.; Li, X.-Y. Zeolite-based hemostat QuikClot releases calcium into blood and promotes blood coagulation in vitro. Acta Pharmacol. Sin. 2013, 34, 367-372. [CrossRef]

41. Selvam, T.; Schwieger, W.; Dathe, W. Histamine-binding capacities of different natural zeolites: A comparative study. Environ. Geochem. Health 2018, 40, 2657-2665. [CrossRef]

42. Vogler, E.A.; Siedlecki, C.A. Contact activation of blood-plasma coagulation. Biomaterials 2009, 30, 1857-1869. [CrossRef] [PubMed]

43. Sperling, C.; Fischer, M.; Maitz, M.F.; Werner, C. Blood coagulation on biomaterials requires the combination of distinct activation processes. Biomaterials 2009, 30, 4447-4456. [CrossRef] [PubMed] 
44. Sun, X.; Tang, Z.; Pan, M.; Wang, Z.; Yang, H.; Liu, H. Chitosan/kaolin composite porous microspheres with high hemostatic efficacy. Carbohydr. Polym. 2017, 177, 135-143. [CrossRef] [PubMed]

45. Udangawa, R.N.; Mikael, P.E.; Mancinelli, C.; Chapman, C.; Willard, C.F.; Simmons, T.J.; Linhardt, R.J. Novel Cellulose-Halloysite Hemostatic Nanocomposite Fibers with a Dramatic Reduction in Human Plasma Coagulation Time. ACS Appl. Mater. Interfaces 2019, 11, 15447-15456. [CrossRef] [PubMed]

46. Kieliszek, M.; Lipinski, B.; Blazejak, S. Application of Sodium Selenite in the Prevention and Treatment of Cancers. Cells 2017, 6, 39. [CrossRef] [PubMed]

47. Kieliszek, M.; Lipinski, B. Pathophysiological significance of protein hydrophobic interactions: An emerging hypothesis. Med. Hypotheses 2018, 110, 15-22. [CrossRef] [PubMed]

48. Lipinski, B.; Pretorius, E. Novel pathway of iron-induced blood coagulation: Implications for diabetes mellitus and its complications. Pol. Arch. Med. Wewnętrznej 2012, 122, 115-122. [CrossRef]

49. Wang, X.; Hu, L.; Li, C.; Gan, L.; He, M.; He, X.; Tian, W.; Li, M.; Xu, L.; Li, Y. Improvement in physical and biological properties of chitosan/soy protein films by surface grafted heparin. Int. J. Biol. Macromol. 2016, 83, 19-29. [CrossRef] [PubMed]

50. Senoussi, H.; Osmani, H.; Courtois, C.; Bourahli, M.e.H. Mineralogical and chemical characterization of DD3 kaolin from the east of Algeria. Boletín De La Soc. Española De Cerámica Y Vidr. 2016, 55, 121-126. [CrossRef]

51. Zhu, X.J.; Jiang-Tao, H.E.; Si-Hui, S.U. Forming Mechanism of Humic Acid-Kaolin Complexes and the Adsorption of Trichloroethylene. Environ. Sci. 2015, 36, 227-236.

52. Kheirabadi, B.S.; Scherer, M.R.; Estep, J.S.; Dubick, M.A.; Holcomb, J.B. Determination of efficacy of new hemostatic dressings in a model of extremity arterial hemorrhage in swine. J. Trauma Acute Care Surg. 2009, 67, 450-460. [CrossRef] [PubMed]

53. Wu, K.; Feng, R.; Jiao, Y.; Zhou, C. Effect of halloysite nanotubes on the structure and function of important multiple blood components. Mater. Sci. Eng. C Mater. Biol. Appl. 2017, 75, 72-78. [CrossRef] [PubMed]

54. Chaturvedi, A.; Dowling, M.B.; Gustin, J.P.; Scalea, T.M.; Raghavan, S.R.; Pasley, J.D.; Narayan, M. Hydrophobically modified chitosan gauze: A novel topical hemostat. J. Surg. Res. 2017, 207, 45-52. [CrossRef] [PubMed]

55. Gao, L.; Gan, H.; Meng, Z.; Gu, R.; Wu, Z.; Zhang, L.; Zhu, X.; Sun, W.; Li, J.; Zheng, Y. Effects of genipin cross-linking of chitosan hydrogels on cellular adhesion and viability. Colloids Surf. B Biointerfaces 2014, 117, 398-405. [CrossRef] [PubMed]

56. Liang, Y.; Xu, C.; Li, G.; Liu, T.; Liang, J.F.; Wang, X. Graphene-kaolin composite sponge for rapid and riskless hemostasis. Colloids Surf. B Biointerfaces 2018, 169, 168-175. [CrossRef] [PubMed]

Sample Availability: Samples of the compounds are not available from the authors.

(C) 2019 by the authors. Licensee MDPI, Basel, Switzerland. This article is an open access article distributed under the terms and conditions of the Creative Commons Attribution (CC BY) license (http://creativecommons.org/licenses/by/4.0/). 